\title{
Hydraulic Performance Analysis of Emitters under Magnetied Saline Water Conditions
}

Zeinab S Turky ${ }^{1^{*}}$, Yasser E Arafa ${ }^{2}$, Khaled F El-Bagoury ${ }^{2}$, Moustafa M Moustafa ${ }^{1}$

1- Irrigation and Drainage Engineering Dept, Agric Eng, Res Institute, Dokki, Giza, Egypt

2- Agric. Engineering Dept, Fac of Agric, Ain Shams Univ, P.O. Box 68 Hadayek Shoubra 11241, Cairo, Egypt

${ }^{*}$ Corresponding author: zeinabturky66@yahoo.com fore and after magnetic which the average value (1.42 $\mathrm{ms}^{-1}$ to $1.45 \mathrm{~ms}^{-1}$ ) for control and magnetic treatment. Finally, the clogging ratio of emitters (\%) with the magnetic treatment was less than untreated magnetic.

Keywords: Magnetic technique, Salinity water, Water properties, Emitter clogging

\section{Introduction}

The main water supplier in Egypt is the Nile River, which accounts for about $96 \%$ of Egypt's renewable water resources, as well, some monsoon rains on the coast and Sinai, which do not exceed 1.5 billion cubic meters annually. As well as amounts of renewable and non-renewable ground water in deserts. In addition the reuse of waste water, agricultural and sometimes industrial treatment Ferrari et al (2014).

In view of the limited water resources and the increase in the population, other resources have been used with great care in some areas due to the salinity of water sources and their impact on farming and irrigation systems. It increased the salinity of soil and drainage water, maintaining the efficiency of the drip irrigation system and obtaining a satisfactory economic return for various crops and not to leave the land and develop it. Also, the misuse of saline water increase problem in emitter clogging that inversely affects the uniformity of water and causes problems in urgent and alkaline soils, which are reflected in damage of soil properties and the reduction of crop productivity Mojtaba et al (2018). 
The using poor-quality water with salinity is a big problem in agriculture. Magnetized water recommended to improve soil, water and to reduce soil moisture stress Kney and Parsons (2006).

Therefore, modern technologies can be applied to conserve these water resources and improve those that use modern technologies such as magnetic water technology.

When water exposed magnetic force at a constant velocity the treated water is become magnetically. When this happens, some specific changes to their molecular properties occur.

Normal tap water molecules are not discrete from each other due to the presence of hydrogen bonds. They tend to cling to one another and form groups normal water passes through magnetic field, the size of these clusters decreases and the number of collected particles. as a result, the activity of water molecules increases (Ismail et al 2017).

(Tai et al 2008) said that the exposing water to a magnetic field modifies its properties, as it becomes more active and able to flow. Hasaani et al (2015) found that the viscosity and surface tension decreased by a factor of $23 \%$ and $18 \%$, respectively, when applying magnetic fields of density $6560 \mathrm{G}$ which were generated by suitable arrangement of constant magnet pieces around the pipe. As well as the $\mathrm{pH}$ was increased by $12 \%$, while TDS and EC value decreased by $33 \%$ and $36 \%$, respectively. Even, the thermal conductivity reduced by $16 \%$.

(Mojtaba et al 2018) said when using salty water in irrigation and also with increasing time, the emitter clogged but the use of magnetic water was lower compared to non-magnetic treatment. (Kiani et al 2016) said the MWT has a favorable effect in terms of preventing emission clogging due to magnetic water and is softer. In addition, MWT has more benefits on the soil which increasing the filtering of excess soluble salts, reducing $\mathrm{pH}$ values of soil layers, slightly dissolving the soluble salts such as carbonates, phosphates, and sulfates (Hilal et al 2013), which reduces the hydration of salt ions, accelerating clotting and crystallization of salt.

This investigation aims to Evaluate the hydraulic performance for emitters under magnetied saline water. Study of some characteristics water under magnetic treatment. Evaluate the emitter's clogging under different water treatments.

\section{Materials and Methods}

Laboratory experiments for hydraulic tests and measurements were conducted at the National Irrigation Laboratory of Agricultural Engineering Research Institute (AEnRI), Dokki, Giza Governorate, Egypt, to evaluate the following:

The hydraulic performance analysis for emitters under magnetied saline water

The Components were used in the testing are showing in Fig 1.

- Water tank: It made from plastic, cylindrical shape 200 I volume, and water outlet in the bottom.

- Pump: classifications of the pump are (power supply $220 \mathrm{~V}-50 \mathrm{~Hz}-2.6 \mathrm{~A}, 0.5 \mathrm{HP}$, the height flow $40 \mathrm{l} / \mathrm{min}$.

- Filtration: type disc (size 3/4"), 120 mesh / 130 micron and flow rate $3-5 \mathrm{~m}^{3} / \mathrm{hr}$.

- Pressure gauges: fixed before water entering of the lateral to maintain constant pressure.

- Emitter type: built -in (4 L/h at 1 bar and $50 \mathrm{~cm}$ emitters spacing).

- Collectors for catching water from emitters: number of collectors was 25 made of plastic, diameter 11 to $15 \mathrm{~cm}$, height 1 to 1.5 times the diameter.

- Pipes arrangement: polyethylene (LDPE) laterals of (OD) $16 \mathrm{~mm}, 1.3 \mathrm{~mm}$ thickness and $50 \mathrm{~m}$ in length.

Magnetic device: It can be installed via the pipe as showing in Fig 2 and it consists of an internal metal tube and an external stainless-steel tube where the direction of current is vertical with the passage level of the material, size 2.0", flux density 14.5 tesla, total length $81 \mathrm{~cm}$, and magnets length $66 \mathrm{~cm}$.

The hydraulic characteristics for emitters were evaluated according to (ASAE 1996 and MSAE, 2005) Standard through several calculations of (CV, qvar and Eu) under pressures from 0.5 to 1.25 bar, and the rates of flow were calibrated by weighting the water in plastic cylinders in a time of 3 minutes, as indicated by stopwatch. 25 emitters were selected along the drip line $50 \mathrm{~m}$ under salinity levels $\left(0.343 \mathrm{dSm}^{-1}\left(\mathrm{~S}_{1}\right), 3.125 \mathrm{dSm}^{-1}\left(\mathrm{~S}_{2}\right), 5 \mathrm{dSm}^{-1}\left(\mathrm{~S}_{3}\right)\right.$ and $6.25 \mathrm{dSm}^{-1}\left(\mathrm{~S}_{4}\right)$ with and without magnetic device. 


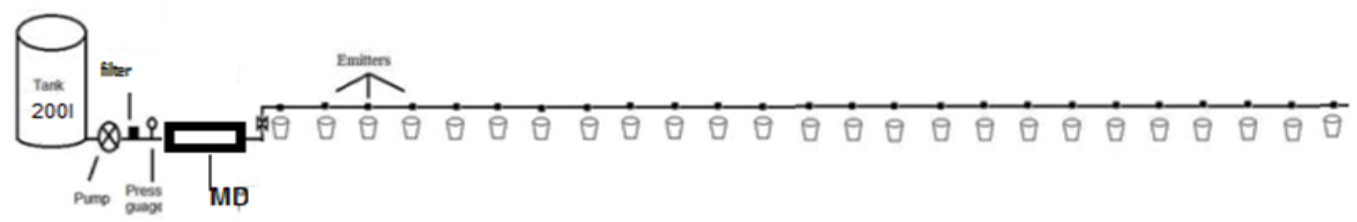

Fig 1. lab experiment layout.

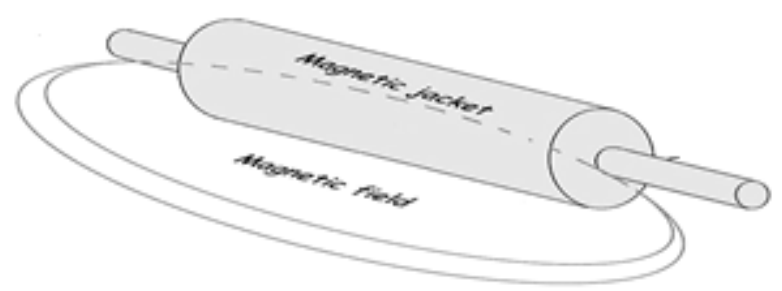

Fig 2. Magnetic device

\subsection{Effect of (MWT) on salinity water properties} at different distances from the drip line

To estimate the impact of MWT on water characterizes (physical and chemical) at different levels of salinity were prepared by mixing varying quantities of salts as Sodium chloride ( $\mathrm{NaCl}$ )" Rashid salt", of fresh water of $\left(.343 \mathrm{dms}^{-1}\right)$ to get the concentration levels of $3.125,5$ and $6.25 \mathrm{dms}^{-1}$ and measuring physical proprieties such as (density, viscosity, and Reynolds number) and chemical proprieties (EC, TDS, and $\mathrm{pH}$ ) after the device outlet immediately and after $25 \mathrm{~m}$ and 50 . The measurements were recorded to recognize the characteristics of water salinity levels used before magnetization. The quantities of salts used in experiment as shown in Table 1.

Table 1. The analysis of water salinity levels (S) used

\begin{tabular}{|c|c|c|c|c|c|}
\hline $\begin{array}{c}\text { Saline } \\
\text { water }\end{array}$ & $\begin{array}{c}\text { Salt } \\
\text { used }\end{array}$ & $\begin{array}{c}\text { Salt } \\
\text { quantity } \\
\text { (g) }\end{array}$ & $\begin{array}{c}\text { TDS } \\
\text { (ppm) }\end{array}$ & pH & $\begin{array}{c}\text { EC } \\
\left.\text { (dms }^{-1}\right)\end{array}$ \\
\hline S1 & & - & 219 & 7.30 & 0.343 \\
S2 & $\mathrm{NaCl}$ & 367.6 & 2000 & 7.53 & 3.125 \\
S3 & & 588.2 & 4000 & 8.04 & 5 \\
S4 & & 735.3 & 5000 & 7.59 & 6.25 \\
\hline
\end{tabular}

\subsection{Instruments were used in the experiment}

Tesla meter: Tesla meter device was used to define the flux density with (Gauss) unit, Model (XHT -1), Accuracy $\pm 0.2 \%$.

EC meter: was used to define the EC of water and Model (EC300), Range 0.0 to $499.9 \mathrm{uS} / \mathrm{cm}, 500$ to $4999 \mathrm{uS} / \mathrm{cm}, 50.0$ to $200.0 \mathrm{mS} / \mathrm{cm}$.

PH meter: $\mathrm{pH}$ meter was used to define the $\mathrm{pH}$ of water, Model ( $\mathrm{pH} 100)$, Range -2.00 to $16.00 \mathrm{PH}$, Accuracy $\pm 0.1 \%,+-2$ lsd.

\subsection{Measurements and calculations}

\subsubsection{Pressure-flow relationships}

The relationship between discharge and pressure from (Keller and Karmeli, 1974) can be expressed as:

Where:

$$
q=\boldsymbol{k p}^{x} \ldots \ldots(1)
$$

$q$ : Emitter flow rate, $(\mathrm{L} / \mathrm{h})$,

$k$ : Constant of characterizes each emitter.

$p$ : Operating pressure, (bar), and

$x$ : Emitter exponent which describes by the flow regime.

The value of " $x$ " describe the type of flow as; Laminar flow

Fully pressure compensating 


\subsection{Variation of the average flow rate from the nominal one}

The pressure influence on emitter discharge variation was calculated according to the following relationship (Keller and Karmeli, 1974) at pressure of 1 bar:

$$
q_{v a r}=\left(\left(q_{\max }-q_{\min }\right) / q_{\max }\right) \times 100 \ldots \ldots
$$

Where:

$\boldsymbol{q}_{\text {var }}:$ The flow variation of emitters, (\%),

$\boldsymbol{q}_{\max }$ : The maximum flow at the lateral, (Iph).

$\boldsymbol{q}_{\min }$ : The minimum flow at the lateral, (Iph).

\subsection{Manufacture's coefficient of variations}

Manufacture's coefficient was calculated by using the following equation (Keller and Karmeli, 1974):

$$
C V=\left(s / q_{a}\right) \times 100 \ldots \ldots(3)
$$

Where:

$C V$ : manufacture's coefficient variation.

$S$ : standard deviation of emitter flow rates at optimum pressure head.

$q_{a}$ : average flow rate of emitter at optimum pressure head, (Iph).

\subsection{Emission uniformity}

Keller and Karmeli, (1974 and 1975) revealed that a statistical uniformity could be used to indicate performance for emitters. as following equation:

$$
\begin{array}{cl} 
& E U=\left(q_{n} / q_{a}\right) \times 100 \ldots \ldots(4) \\
\text { Where: } & \\
E U: & \text { The emission uniformity, (\%), } \\
q_{n}: & \text { The mean of lowest } 1 / 4 \text { of the emitter flow } \\
& \text { rate, in (Lph), and } \\
q_{a}: \begin{array}{l}
\text { The mean of all emitter flow rates, in } \\
\text { (Lph). }
\end{array}
\end{array}
$$

\subsection{Kinematic Viscosity}

Kinematic viscosity is the ratio of absolute viscosity in $\mathrm{N}-\mathrm{s} / \mathrm{m} 2$ to the density of the liquid in $\mathrm{kg} / \mathrm{m} 3$. Mathematically, kinematic viscosity $v(n u)$,

$$
v=\frac{\mu}{\rho} \ldots \ldots(5)
$$

Where:

v: kinematic viscosity, $\left(\mathrm{m}^{2} \mathrm{~s}^{-1}\right)$

$\rho:$ density of liquid, $\left(\mathrm{gcm}^{-3}\right)$

$\mu$ : dynamic viscosity of liquid, (pa.s)

\subsection{Reynolds's number}

The Reynolds (Re) number is used to describe if a fluid flow is laminar or turbulent. (Khurmi 1997).

$$
\operatorname{Re}=\frac{\rho V}{\mu}
$$

Where:

$\mathrm{V}$ : Mean velocity of liquid, $\left(\mathrm{ms}^{-1}\right)$

$\mathrm{d}$ : Diameter of pipe, $(\mathrm{m})$

$\rho$ :density of liquid, $\left(\mathrm{gcm}^{-3}\right)$

$\mu$ : dynamic viscosity, (pa.s)

The flow regimes are usually characterized as:

- Laminar flow $\mathrm{Re}<2000$

- Unstable flow Re> 2000

- Partially turbulent flow $4000<R e<10000$

\subsection{Emitters clogging}

To estimate the emitter flow rate cans and a stopwatch was used. Emitters from lateral had been chosen randomly to calculate the clogging ratio at the beginning and the end of experiment. Clogging ratio was calculated according to (Al-Amoud 1997) using the following equation:

$$
C R=(1-(Q u \div Q n))^{*} 100
$$

Where:

$\mathrm{CR}=$ The emitter clogging ratio, (\%),

$\mathrm{Qu}=$ The flow rates at the end $(\mathrm{l} / \mathrm{h})$, and

$\mathrm{Qn}=$ The flow rates at the beginning $(\mathrm{I} / \mathrm{h})$

\section{Results and Discussion}

\subsection{Effect of (MWT) on saline water properties} under different distance

The data collected on the changes in properties of salinity water that including total dissolved solids (TDS), electrical conductivity (EC), $\mathrm{pH}$, density, velocity and viscosity to study the impact of magnetization process on water at different salinity levels and different distances of lateral.

The results in Table 2 indicated that values of chemical analyses of salinity water $\left(E C\left(\mathrm{dms}^{-1}\right)\right.$, TDS (ppm), pH) which, there is no change in the EC and TDS values for different treatment at before and after the device. In addition, there is no change in values at different distance $(0 \mathrm{~m}, 25 \mathrm{~m}$ and $50 \mathrm{~m})$. The value of salinity does not decrease after the magnetic treatment, because the magnetic technique does not remove the salts, but dismantles and 
Table 2. Effect of (MWT) on chemical properties for salinity water under different distance

\begin{tabular}{|c|c|c|c|c|c|c|c|c|c|c|c|c|}
\hline \multirow{3}{*}{ 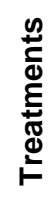 } & \multicolumn{4}{|c|}{$E C\left(d_{S m}^{-1}\right)$} & \multicolumn{4}{|c|}{ TDS (ppm) } & \multicolumn{4}{|c|}{$\mathrm{pH}$} \\
\hline & \multirow{2}{*}{$\begin{array}{c}\text { Non } \\
\text { magnetic }\end{array}$} & \multicolumn{3}{|c|}{ Magnetic treated } & \multirow{2}{*}{$\begin{array}{c}\text { Non } \\
\text { magnetic }\end{array}$} & \multicolumn{3}{|c|}{ Magnetic treated } & \multirow{2}{*}{$\begin{array}{c}\text { Non } \\
\text { magnetic }\end{array}$} & \multicolumn{3}{|c|}{ Magnetic treated } \\
\hline & & $0 \mathrm{~m}$ & $25 \mathrm{~m}$ & $50 \mathrm{~m}$ & & $0 \mathrm{~m}$ & $25 m$ & $50 \mathrm{~m}$ & & $0 \mathrm{~m}$ & $25 m$ & $50 \mathrm{~m}$ \\
\hline $\mathrm{S}_{1}$ & 0.343 & 0.343 & 0.343 & 0.343 & 219 & 219 & 219 & 219 & 7.30 & 7.38 & 7.58 & 7.97 \\
\hline $\mathrm{S}_{2}$ & 3.125 & 3.125 & 3.125 & 3.125 & 2000 & 2000 & 2000 & 2000 & 7.53 & 7.59 & 7.67 & 7.79 \\
\hline $\mathrm{S}_{3}$ & 5.0 & 5.00 & 5.00 & 5.00 & 4000 & 4000 & 4000 & 4000 & 8.04 & 8.12 & 8.19 & 8.22 \\
\hline $\mathrm{S}_{4}$ & 6.25 & 6.25 & 6.25 & 6.25 & 5000 & 5000 & 5000 & 5000 & 7.59 & 7.88 & 7.97 & 8.00 \\
\hline
\end{tabular}

break up the salt crystals into very small particles, the plant gets its needs from the salts dissolved in the water and the rest of the salts that do not need the plant to the ground with wastewater. These results are harmonious with (Zeinab et al 2016).

Data in the same table showed that the values of the $\mathrm{pH}$ water were changed after magnetic treated where the $\mathrm{pH}$ increased from (7.30 to 7.64) for $\mathrm{s}_{1}$ before and after magnetic treated, from $(7.53$ to 7.68 ) for $\mathrm{s}_{2}$, from (8.04 to 8.17) for $\mathrm{s}_{3}$ and from (7.59 to7.95) for $\mathrm{s}_{4}$. Also the $\mathrm{pH}$ was increased at different distances $(0 \mathrm{~m}, 25 \mathrm{~m}, 50)$, Consequently, the effect of MWT continues for $50 \mathrm{~m}$. The increase in the value of $\mathrm{pH}$ is due to the occurrence of water ionization due to magnetic force and the process of ionization results in an increase of anions of bicarbonate, calcium, hydroxide and alkaline substances and a change in the characterizes of water. This result agrees with, Hassani et al (2015) and Tai et al (2008).

Moreover, Data in Table 3 showed that the values of physical properties of salinity water the density $\left(\mathrm{gm} \mathrm{cm}^{-3}\right)$, and viscosity $\left(\mathrm{mm}^{2} \mathrm{~s}^{-1}\right)$ decreased under magnetic treatment compared to non- magnetic which density $\left(\mathrm{gm} \mathrm{cm}^{-3}\right)$, from $(0.974$ to 0.944$)$, (0.988 to 0.956$),(0.993$ to 0.965$)$ and from (1.003to $0.974)$ for $S_{1}, S_{2}, S_{3}, S_{4}$, respectively. Also, the velocity was no significant effect before and after magnetic which the average $\left(1.42 \mathrm{~ms}^{-1}\right.$ to $\left.1.45 \mathrm{~ms}^{-1}\right)$ for control and magnetic treatment in addition to, the values of viscosity $\left(\mathrm{mm}^{2} \mathrm{~s}^{-1}\right)$ were $(0.902,0.934$, $0.922,0.935)$ under magnetic treatment compared to non- magnetic $(1.004,0.966,0.961,0.975)$ for $S_{1}$, $\mathrm{S}_{2}, \mathrm{~S}_{3}, \mathrm{~S}_{4}$ treatments respectively. These results are harmonious with Hasaani et al (2015).
3.2 Effect of MWT under different salinity water on the hydraulic performance for emitters and emission uniformity

\subsubsection{Performance and evaluation of the built-in emitters}

Fig 3 and Table 4 showed that the relationship between emitter flow rates and pressure for emitter (built-in) all data indicated that according to ASAE standard, the built-in emitters were acceptable in all tested parameters like CV, Eu, and qvar. in the evaluation, CV was $2.94 \%$ and was acceptable according to ASAE Standard and was excellent. Eu = 95.75\% excellent, $q_{v a r}=9.88 \%$ acceptable and flow regime turbulent.

\subsection{Effect of MWT for salinity water on flow rate and emission uniformity}

Table 5 showed that the data after evaluating the emitter hydraulic performance in all treatments. It appears that emitter hydraulic performance in $(\mathrm{Eu}$, qavr) $\%$ is all excellent where, the use of magnetic water for emitters caused higher uniformity whish, the maximum values ( $96.11 \%$ to $94.88 \%$ ) at the beginning and end the experiment for $\mathrm{s}_{1}$ for magnetic and the discharge $(4.69$ to $4.44 \mathrm{l} / \mathrm{h})$, but the minimum values (94.15\% to $75.29 \%)$ at the beginning and end the experiment for $\mathrm{s}_{4}$ for nonmagnetic .In addition to ,the discharge for emitters through along laterals under magnetic and nonmagnetic treated (control), increases with MWT compared to magnetic untreated on line drip. Where, $S_{1} q_{a v r}=4.69 \mathrm{I} / \mathrm{h}$ to $4.41 \mathrm{l} / \mathrm{h}$ for magnetic treated and magnetic 
Table 3. Effect of MWT on physical properties for saline water

\begin{tabular}{|c|c|c|c|c|c|c|}
\hline \multirow{2}{*}{ Treatment } & \multicolumn{2}{|c|}{ Density $\left(\mathrm{gmcm}^{-3}\right)$} & \multicolumn{2}{c|}{ Velocity $\left(\mathrm{ms}^{-1}\right)$} & \multicolumn{2}{c|}{ viscosity $\left(\mathbf{x}^{-1} \mathbf{0}^{-6} \mathbf{m}^{2} \mathbf{s}^{-1}\right)$} \\
\cline { 2 - 7 } & $\begin{array}{c}\text { Non } \\
\text { magnetic }\end{array}$ & $\begin{array}{c}\text { Magnetic } \\
\text { treated }\end{array}$ & $\begin{array}{c}\text { Non } \\
\text { magnetic }\end{array}$ & $\begin{array}{c}\text { Magnetic } \\
\text { treated }\end{array}$ & $\begin{array}{c}\text { Non } \\
\text { magnetic }\end{array}$ & $\begin{array}{c}\text { Magnetic } \\
\text { treated }\end{array}$ \\
\hline $\mathrm{S}_{1}$ & 0.974 & 0.944 & 1.43 & 1.46 & 1.004 & 0.902 \\
$\mathrm{~S}_{2}$ & 0.988 & 0.956 & 1.42 & 1.45 & 0.966 & 0.934 \\
$\mathrm{~S}_{3}$ & 0.993 & 0.965 & 1.42 & 1.44 & 0.961 & 0.922 \\
$\mathrm{~S}_{4}$ & 1.003 & .0 .974 & 1.41 & 1.43 & 0.975 & 0.935 \\
\hline
\end{tabular}

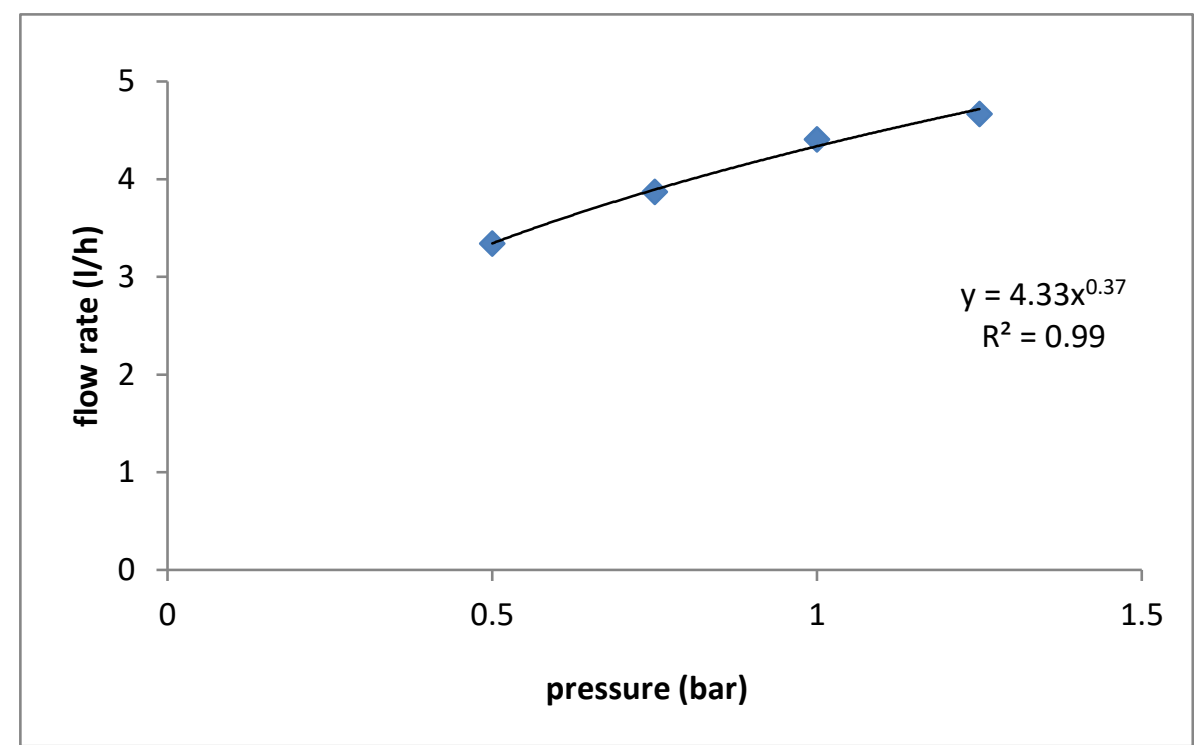

Fig 3. Pressure- flow relationships: $q=k p^{x}$

Table 4. Hydraulic characteristics for tested emitters at 1 bar

\begin{tabular}{|c|c|c|}
\hline \multicolumn{2}{|c|}{ Hydraulic characteristics } & \multirow[b]{2}{*}{8.82} \\
\hline Flow rate $(\mathrm{I} / \mathrm{h} / \mathrm{m})$ & Nominal & \\
\hline $\begin{array}{l}\text { Manufacture's coefficient of variation } \\
\text { (CV \%) at } 1 \text { bar }\end{array}$ & $\begin{array}{c}\text { Value } \\
\text { ASAE standard }\end{array}$ & $\begin{array}{c}2.94 \\
\text { Excellent }\end{array}$ \\
\hline Parameters & $\begin{array}{l}\text { Emitter discharge exponent(x) } \\
\text { Flow coefficient(k) }\end{array}$ & $\begin{array}{c}.37 \\
4.33\end{array}$ \\
\hline \multicolumn{2}{|c|}{ Flow regime } & Turbulent flow \\
\hline Emission uniformity (Eu\%) & $\begin{array}{c}\text { Value } \\
\text { ASAE standard }\end{array}$ & $\begin{array}{c}95.75 \\
\text { Excellent }\end{array}$ \\
\hline Emitter flow variation (qvar\%) & $\begin{array}{c}\text { Value } \\
\text { Classification }\end{array}$ & $\begin{array}{c}9.88 \\
\text { Acceptable }\end{array}$ \\
\hline
\end{tabular}


Table 5. Effect of MWT for salinity water on flow rate and emission uniformity

\begin{tabular}{|c|c|c|c|c|c|c|c|c|}
\hline \multirow{3}{*}{ Treatment } & \multicolumn{4}{|c|}{ Flow rate(l/h) } & \multicolumn{4}{|c|}{ Eu (\%) } \\
\hline & \multicolumn{2}{|c|}{$\begin{array}{l}\text { At the first } \\
\text { experiment }\end{array}$} & \multicolumn{2}{|c|}{$\begin{array}{l}\text { At the end } \\
\text { experiment }\end{array}$} & \multicolumn{2}{|c|}{$\begin{array}{l}\text { At the first } \\
\text { experiment }\end{array}$} & \multicolumn{2}{|c|}{$\begin{array}{l}\text { At the end } \\
\text { experiment }\end{array}$} \\
\hline & $\begin{array}{c}\text { Non- } \\
\text { magnetic } \\
\text { treated }\end{array}$ & $\begin{array}{c}\text { Magnetic } \\
\text { treated }\end{array}$ & $\begin{array}{c}\text { Non- } \\
\text { magnetic } \\
\text { treated } \\
\end{array}$ & $\begin{array}{c}\text { Magnetic } \\
\text { treated }\end{array}$ & $\begin{array}{c}\text { Non- } \\
\text { magnetic } \\
\text { treated }\end{array}$ & $\begin{array}{c}\text { Magnetic } \\
\text { treated }\end{array}$ & $\begin{array}{c}\text { Non- } \\
\text { magnetic } \\
\text { treated }\end{array}$ & $\begin{array}{c}\text { Magnetic } \\
\text { treated }\end{array}$ \\
\hline $\mathrm{S}_{1}$ & 4.41 & 4.69 & 4.08 & 4.44 & $\begin{array}{c}95.75 \\
\text { (excellent) }\end{array}$ & $\begin{array}{c}96.11 \\
\text { (excellent) }\end{array}$ & $\begin{array}{c}92.69 \\
\text { (excellent) }\end{array}$ & $\begin{array}{c}94.88 \\
\text { (excellent) }\end{array}$ \\
\hline $\mathrm{S}_{2}$ & 4.18 & 4.64 & 3.59 & 4.21 & $\begin{array}{c}94.96 \\
\text { (excellent) }\end{array}$ & $\begin{array}{c}95.50 \\
\text { (excellent) }\end{array}$ & $\begin{array}{c}86.12 \\
\text { (good) }\end{array}$ & $\begin{array}{c}90.83 \\
\text { (excellent) }\end{array}$ \\
\hline $\mathrm{S}_{3}$ & 4.33 & 4.41 & 3.47 & 3.90 & $\begin{array}{c}94.51 \\
\text { (excellent) }\end{array}$ & $\begin{array}{c}95.56 \\
\text { (excellent) }\end{array}$ & $\begin{array}{l}80.14 \\
\text { (fair) }\end{array}$ & $\begin{array}{l}88.59 \\
\text { (good) }\end{array}$ \\
\hline $\mathrm{S}_{4}$ & 4.19 & 4.38 & 3.15 & 3.79 & $\begin{array}{c}94.15 \\
\text { (excellent) }\end{array}$ & $\begin{array}{c}95.39 \\
\text { (excellent) }\end{array}$ & $\begin{array}{l}75.29 \\
\text { (fair) }\end{array}$ & $\begin{array}{l}86.59 \\
\text { (good) }\end{array}$ \\
\hline
\end{tabular}

untreated, $S_{2} q_{a v r}=4.64 \mathrm{l} / \mathrm{h}$ to $4.18 \mathrm{l} / \mathrm{h}, \mathrm{S}_{3} \mathrm{q}_{\mathrm{var}}=4.41$ to $4.33 \mathrm{l} / \mathrm{h}$ and $\mathrm{S}_{4} \mathrm{q}_{\mathrm{avr}}=4.38$ to $4.19 \mathrm{l} / \mathrm{h}$. The higher uniformity and increase the average emitters discharge due to the change in water properties such as decrease in density and viscosity so the water becomes more energetic and able to flow. This study agree with Tai et al (2008).

\subsection{Effect of MWT for salinity water on Reynolds number}

Data in Table 6 indicated that the values of Re which increase with MWT compared to non- magnetic, but there is no significant difference between the values, especially at the beginning of the experiment, where the flow was described as turbulent with different salinity levels .at the end of experiment the flow was as turbulent for magnetic treated, but the values were decreases compared to the beginning. The maximum value of $\mathrm{Re}$ was (2460.3) for $\mathrm{s}_{1}$ while the minimum value was (2128.9) for $s_{4}$.but the magnetic untreated the flow was change from turbulent to laminar because of the accumulation of salts. The change between magnetic and nonmagnetic due to the low viscosity and density so the MWT improves the flow hydraulic.

\subsection{Effect of MWT on emitter clogging}

Clogging in emitters can effect on emission uniformity and the performance for irrigation, which has relationship with water quality so emitter clogging with increase of time and the salinity level of irrigation water increased. These results in Table 7 show that the emitter discharge variations for the magnetic treatment were lower than the magnetic untreated which indicates less dripper clogging where the emitter clogging ratio $(7.3,13.8,19.8,24.7 \%)$ for magnetic untreated but the emitter clogging ratio for magnetic treated is $(5.1,9.1,11.4,13.4 \%)$, the clogging ratio decrease because of the increase in turbulent flow for magnetic water and decrease the accumulation the salts compared to nonmagnetic. so, we can use magnetic technique to solving the problems of emitter clogging with applied of saline water. This study concurs with Kiani et al (2016). 
Table 6. Effect of MWT for salinity water on Reynolds number

\begin{tabular}{|c|c|c|c|c|}
\hline \multirow{3}{*}{ Treatment } & \multicolumn{4}{|c|}{$\mathbf{R e}$} \\
\hline & \multicolumn{2}{|c|}{ At the first experiment } & \multicolumn{2}{|c|}{ At the end experiment } \\
\hline & $\begin{array}{c}\text { Non-magnetic } \\
\text { treated }\end{array}$ & $\begin{array}{c}\text { Magnetic } \\
\text { treated }\end{array}$ & $\begin{array}{c}\text { Non-magnetic } \\
\text { treated }\end{array}$ & Magnetic treated \\
\hline$S_{1}$ & 2279.8 & 2589.8 & 844.6 & 2460.3 \\
\hline $\mathrm{S}_{2}$ & 2351.9 & 2483.9 & 828.2 & 2260.3 \\
\hline $\mathrm{S}_{3}$ & 2364.2 & 2498.9 & 799.2 & 2224.0 \\
\hline $\mathrm{S}_{4}$ & 2313.8 & 2447 & 722 & 2128.9 \\
\hline
\end{tabular}

Table 7. Effect of MWT for salinity water on emitter clogging

\begin{tabular}{|c|c|c|}
\hline \multirow{2}{*}{ Treatment } & \multicolumn{2}{|c|}{ Clogging ratio (\%) } \\
\cline { 2 - 3 } & $\begin{array}{c}\text { Magnetic } \\
\text { treatment }\end{array}$ & $\begin{array}{c}\text { Magnetic } \\
\text { untreated }\end{array}$ \\
\hline $\mathrm{S}_{1}$ & 5.12 & 7.31 \\
$\mathrm{~S}_{2}$ & 9.17 & 13.88 \\
$\mathrm{~S}_{3}$ & 11.41 & 19.86 \\
$\mathrm{~S}_{4}$ & 13.41 & 24.71 \\
\hline
\end{tabular}

\section{Conclusion}

The applying of magnetic water for drip irrigation caused increase the average dripper discharge and higher uniformity compared to the non-magnetic water so the magnetic technology can save the water. The EC and TDS contents did not change after and before magnetic treated, but the $\mathrm{pH}$ increases after magnetic as well as the density and viscosity decreased after magnetic. In addition to improve the flow hydraulic. The using magnetized water was decreasing the emitter clogging. Therefore, the applying of magnetic treatment has a good role in improving the hydraulic properties of emitters and reducing the clogging ratio. Therefore, it is suggest using magnetized treated water for drip irrigation.

\section{Reference}

AL-Amoud, Al (1997) Trickle Irrigation System, King Sand University pp. 137-143.

ASAE Standards (1996) Field evaluation of microirrigation systems. St Joseph Mich EP458 ASAE: 43, 756-761.

Esmaeilnezhad, E; Choi, HJ; Schaffie, M; Gholizadeh, M; Ranjbar, M (2017) Characteristics and applications of magnetized water as a green technology. J Clean Prod 161, 908-921. doi: 10.1016/j.jclepro.05.166. [CrossRef] [Google Scholar

Ferrari, E; McDonald, S; Osman, R (2014) Water Scarcity and Irrigation Efficiency in Egypt, New Challenges in Food Policy, Trade and Economic Vulnerability Dakar, Senegal. https://www.gtap.agecon.purdue.edu/resources/download/7118.pdf

Hassan, KK (2015) Magnetic Treatment of Brackish Water for Sustainable Agriculture, MSc. in Environmental Eng. School of Sci. and Eng., American University Cairo, Egypt. http://dar.aucegypt.edu/bitstream/handle/10526/4538/Final\%20. Thesis \% 20 Draft_Kareem \%20 Hassan_\%2027. 12.2015.pdf? seq uence.

Hilal, MH; El-Fakhrani, YM; Mabrouk, SS; Mohamed, AL; Ebead, BM (2013) Effect of magnetic treated irrigation water on salt removal from a sandy soil and on the availability of certain nutrients. Int $J$ Eng Appl Sci 2, 36-44. 

Water Conditions

Keller, J; Karmeli, D (1974) Trickle irrigation design parameters. Trans. of ASAE 17, 678-684.

Keller, J; Karmeli, D (1975) Trickle irrigation design. $1^{\text {st }}$ Ed., Rain Bird Co., Glendora, CA: 133 p.

Khurmi, RS (1997) Hydraulics, Fluid Mechanics and Hydraulic Machines. Printed in India By Rajendra Rovlndra Printers (Pvt.) Ltd., Rom Nogor. New Delhl-110 055 and published by S. Chand \& Company Ltd., Rom Nagor. New Delhl-110 055. ISBN: 81-219-0162-6.

Kiani, A; Hezarjaribi, A; Dehghan, T; Khoshravesh, M (2016) An Investigation of Emitters Clogging Under Magnetic Field and Water Quality. Majallah-iāb va Khāk 29, 48-57.
Mojtaba, K; Sayyed, M; Javad, M; Pooya, S; Reza, NV (2018) Evaluation of dripper clogging using magnetic water in drip irrigation. Applied Water Science 8, 81.

Tai CY; Wu, CK; Chang, MC (2008) Effects of magnetic field on the crystallization of $\mathrm{CaCO} 3$ using permanent magnets. Chem Engin Sci 63, 5606-5612.

Zeinab, ZK; Mona, HI (2016) Some ecological studies on the impact of magnetic field on the tap water Egypt $J$ Aquat Biol \& Fish 20, 51-60. 


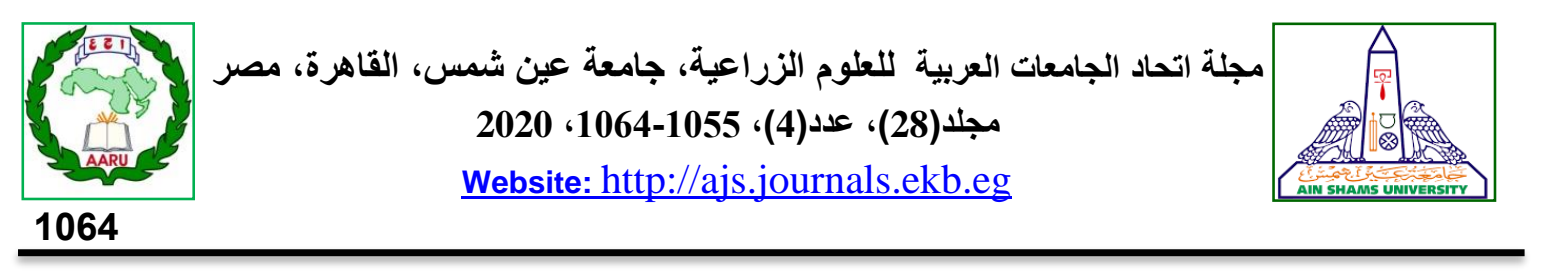

تحليل الآداء الهيدروليكى للمنقطات تحت ظروف الماء المالح الممغنط

[74]

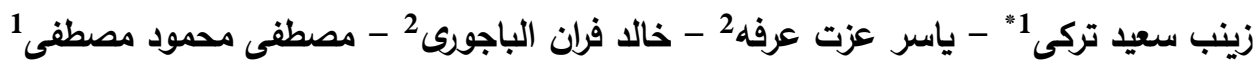

$$
\begin{aligned}
& \text { 1- قسم الرى والصرف الحقلى - معهد بحوث الهندسة الزراعية - مركز البحوث الزراعية }
\end{aligned}
$$

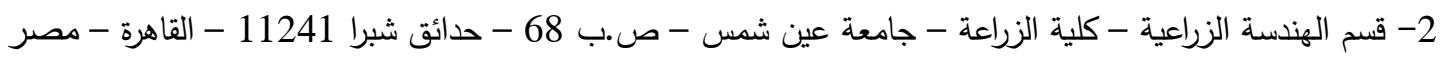

*Corresponding author: zeinabturky66@yahoo.com

حيث جاء متوسط التصرف لعينات المنقطات المستخدمة

: 4.33 : 4.41، 4.18 : 4.64 : 4.41 : 4.69)

4.38 : 4.19 لتر /ساعة). وذللك للمعالجة المغناطيسية

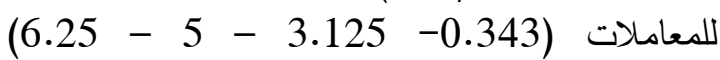

ديسمينز /م على الترتيب. بالإضافة إلى أنه لم يتم حدوث

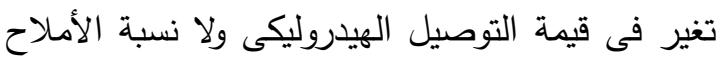

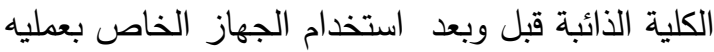
المغنطة ولكن حدث تغير الرقم الهيدروجيينى وظلئل التاثير إلي مسافة 50م (طول خط التغذية). وايضا قلت الت التئن قيم اللزوجة والكثافة بعد المعالجة المغناطسية وكذلك زاد التئ رقم رينولدز •. وفى نهاية التجربة تم تقدير نسبة الإنسداد

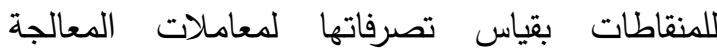

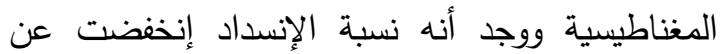
إستخدام الماء العادى دون مغنطة وكانت نسب الإنسداد

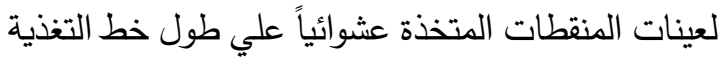
للمياه المعالجة مغناطيسيا اقل بالمقارنه بالمياه المياه المالحة

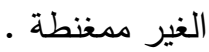

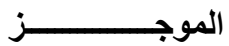

تم إجراء التجارب بالمعمل القومي لإختبارات الري

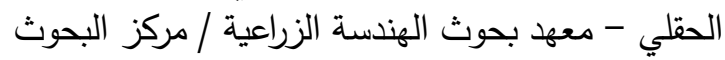
الزراعية (مصر ). وذللك لتقييم تاثير تقنية مغنطة المياه

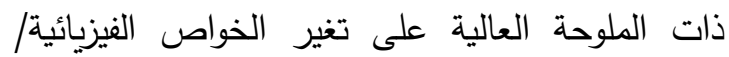
الكيمائية للمياه المالحة (التوصيل الكهربي - خواص الكيل

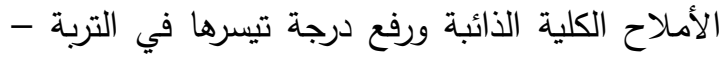

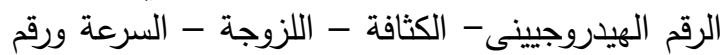
رينولدز) وعلي الخواص الهيدروليكية للنقاطات من ناحية الكاتية

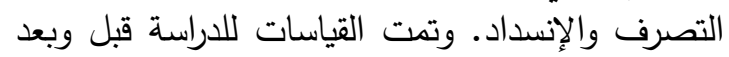
جهاز المغنطة وعلى مسافات مختلفة. وذلك تحت تاثير أربع مستويات ذات تركيز مختلف من المياه المالحة (0.343- 3.125 - 5 - 6.25) ديسمينز/م. أظهرت النتائج (المعملية) أن المعالجة المغناطيسية تسبب فى زيادة كفاءة إنتظامية توزيع المياه نتيجة لإنتظامية تصرف المنقطات المستخدمة (الغير منتظمة

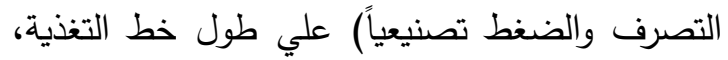

